\title{
BARRIERS AND DRIVERS FOR INNOVATION IN TIMES OF CRISIS
}

\section{Ana Clara Cândidoํ, Patrícia Feronha Wielevick², Ricardo Augusto Zimmermann³}

${ }^{1}$ Universidade do Estado de Santa Catarina - UFSC - e-mail: acc.anaclara@gmail.com

2 Universidade do Porto - e-mail: patriciafw@gmail.com

${ }^{3}$ Universidade de Aveiro - e-mail: ricardoaz@gmail.com

\section{KEYWORDS}

Innovation;

Crisis;

Portugal;

Received 16.11.2015

Revised 02.08.2016

Accepted 08.08. 2016

ISSN 1980-4431

Double blind review

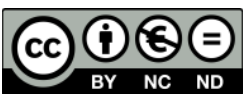

\begin{abstract}
The economic crisis which started in 2008 has demonstrated more clearly the importance of conjuncture aspects for organizational results evidencing associated opportunities and vulnerabilities. In such a context, if on one hand innovation is affected by investment reduction by most enterprises, on the other it has shown to be one of the "antidotes" against the crisis and appears as fertile soil for investments, in the organizational as well as in the territorial context. Enterprises and countries which maintained or even raised efforts toward innovation have demonstrated a higher resilience in times of difficulty. This study aims at identifying opportunities and threats to the innovation performance of firms by means of the study of the crisis effects upon external facilitators and barriers. Besides the literature review, case studies developed in Portuguese and Brazilian enterprises are used for the analysis of the practical effects of the identified aspects in two distinct realities in what concerns the economic crisis. The results show that although Portugal has suffered the crisis effects, in a general way, more than Brazil, when we look to innovation performance, Portugal has shown better results than Brazil during and after the crisis. This study contributes to enterprise and academic purposes since it classifies factors which influence innovation positive or negatively in times of crisis.
\end{abstract}

\section{Introduction}

The economic crisis which started in 2008 has demonstrated more clearly the importance of conjuncture aspects for organizational results evidencing associated opportunities and vulnerabilities (Dervitsiotis, 2010). In such a context, if on one hand innovation is affected by investment reduction by most enterprises, on the other it has shown to be one of the "antidotes" against the crisis and appears as fertile soil for investments, in the organizational as well as in the territorial context (Filippetti \& Archibugi, 2011).

Enterprises and countries which maintained or even raised efforts toward innovation have demonstrated a higher resilience in times of difficulty. We can say, therefore, that the adoption of innovation strategies, as well as contribute to the increased competitiveness of organizations, for economic growth, job creation and the increasing wealth of the territories (Madrid-Guijarro, Garcia, \& Van Auken, 2009), is a defense mechanism against the adversities imposed by any changes in the economic context. The innovation capacity of the organizations is the result of internal and external factors (Berghman, Matthyssens, \& Vandenbempt, 2012; Dervitsiotis, 2010; Fawcett, Jones, \& Fawcett, 2012; Hadjimanolis, 1999; Madrid-Guijarro et al., 2009; Roy, Sivakumar, \& Wilkinson, 2004). Among the 
major internal factors that influence innovation are: organizational culture, leadership for innovation, innovation strategy, availability of internal resources, technology ownership and participation of employees (Dervitsiotis, 2010; Gnyawali \& Srivastava, 2013). External factors, however, include various aspects that relate to environmental, market and relations of companies with other actors. The increasing complexity of entrepreneurial environments, result of globalization, increases the impact of external factors to the overall performance of organizations. These factors, therefore, tend to be more affected in times of crisis.

The crisis effects upon innovation process have been explored in recent literature thanks to the scope of its impact. Ranga \& Etzkowitz (2012) affirm that "innovation has been hit hard by the economic crisis, as $\mathrm{R} \& \mathrm{D}$ spending declined in many countries". On the other hand, some enterprises can follow the opposite direction, taking advantage of new opportunities. The crisis led to a concentration of innovation in a small group of fast growing new firms and those firms already highly innovative before the crisis (Archibugi, Filippetti, \& Frenz, 2013a). Thus, we can say that the moments of severe economic recession affect companies in different ways, depending on the profile and bound to innovate. Similarly, the crisis affects countries differently. On the one hand, Europe was strongly affected by the crisis, and Portugal was one of the countries that faced more difficulties at this time, and on the other hand Brazil is not considered one of the countries that most suffered the effects of the economic crisis.

With regards to the innovation scenery in both countries, Portugal has been positioned ahead of Brazil. According to The Global Innovation Index 2014 (Cornell University, INSEAD, \& WIPO, 2014), Brazil occupies the 61st position in the global innovation ranking between 143 countries availed. Portugal, on the other hand, occupies the 32th position and has shown good results in some important indicators, especially with regards to the politic and governmental environments and the human capital and research. It is noteworthy that, although in a general matter, Portugal has suffered more the effects of the crisis when compared to Brazil, innovation results show a different scenario and Portugal has shown a strongest growth in recent years.
Once the origin of the crisis is economic, as the main consequences, it is natural that the strongest effects upon the innovation process are also economic related, which is reflected in the reduction of the amount invested in innovation by companies. The literature on the effects of crisis upon innovation processes thoroughly explores financial and economic aspects and other aspects are rarely addressed, such as the development of partnerships with clients, suppliers and universities. According to Ranga \& Etzkowitz (2012), the crisis triggered two main effects; affected the innovation system directly due to the reduction of investments, and indirectly aggravating existing systemic weaknesses in a process of "creative destruction" (concept originally used by Joseph Schumpeter and that will be explored in this article).

In such a context, this article aims to explore this existing gap in the literature by means of the study of the various effects of the crisis upon the innovation process, based on the barriers and facilitators (or drivers) that have impact in this process. Thus, the study aims at identifying opportunities and threats to the innovation performance of firms by means of the study of the crisis effects upon external facilitators and barriers. For this, will be explored the concept of persistence of innovation during periods of severe recession. The persistence of innovation concerns the extent to which the organizations that innovate once are more or less likely to innovate again in subsequent periods (Clausen, Pohjola, Sapprasert, \& Verspagen, 2012).

We emphasize that this article does not intend to discuss the causes of the economic crisis but its effects, particularly on the process of innovation of organizations. Thus, although we consider extremely important the study of factors that lead to moments of low economic growth, this issue will not be discussed in depth in this paper.

In addition to a review of the literature that addresses the issues "crisis and innovation" and "barriers and drivers for innovation", we analyze the scenarios of Brazil and Portugal, first with the use of secondary data on innovation in both countries and then analyzing case studies in four organizations, two in each country. From the conclusions of the case studies are pointed out the effects of the crisis on the companies studied,

Revista de Negócios, v. 20, n. 4, p. 1-10, October, 2016. 
which allows, in addition to diagnosis, the comparison between the two realities.

The paper is structured as follows. Next section introduces our theoretical framework about innovation and crisis, barriers and drivers for innovation. Following, the hypotheses are developed and dataset and methodology are introduced. Finally, we present the results that are discussed in the last section.

\section{Innovation and crisis}

Nowadays innovation represents an important advantage for organizations. The innovation capacity of organizations derives from internal and external factors and therefore the economic crisis has impact in such a process in different ways especially on the reduction of investments made by enterprises (Archibugi et al., 2013a; Archibugi, Filippetti, \& Frenz, 2013b; Filippetti \& Archibugi, 2011). Schumpeter (1943) suggested that economic cycles are a consequence of innovation, but also that innovative activities and organizations are strongly affected by economic crises. Filippetti \& Archibugi (2011), following Schumpeter, argue that the relation between innovation and the economic cycles can be summed up into two hypotheses: (1) innovation is a cyclic process and enterprises tend to reduce efforts to innovate during economic recession periods (2) recession periods are fertile ambience for enterprises to innovate. Archibugi, Filippetti, \& Frenz (2013a, p. 306), suggest that "because innovation is risky as well as costly, during a crisis many firms might focus more strongly on survival, and less on seeking out new opportunities". Thus the financial crisis has reduced the short-term willingness of companies to invest in innovation (Archibugi et al., 2013a, 2013b). However, some enterprises manage to go the other way around and take advantage of opportunities emerging from less economic growth to lever up innovation activities.

Archibugi et al (2013a), are still using Schumpeter's model that can be labeled 'creative destruction' and 'creative accumulation' (or 'technological accumulation'), classify enterprises which innovate in periods of crisis in two types: (a) firms that cannot survive without changing their products and services. These dynamic firms innovate continuously, regardless of the business environment. (b) firms that were not necessarily involved in innovation before the crisis, or the new innovators. Such enterprises are usually SMEs which had activities before the crisis or even new enterprises which take advantage of opportunities deriving from the crisis (Archibugi et al., 2013a). For the authors, the first scenery suggests that innovation is based on a cumulative learning process and path-dependent patterns rooted in organizational routines, what confers persistence to the innovation activity. According to the second scenery, economic turbulences made possible for new and small firms to stand out in the competitive market by means of innovation (Archibugi et al., 2013a).

Ranga \& Etzkowitz (2012) also make use of Schumpeter's model to feature the crisis effects. For the authors, the crisis causes two main effects: it affects the innovation system directly due to the reduction of investments as well as indirectly since it accentuates the existing systemic weaknesses in a "creative destruction" process. Kanerva \& Hollanders (2009), analyzing data from Eurobarometer, suggest that highly innovative firms continued to invest in innovation also during the crisis, depending on the 'persistence of innovation'. It's one of the factors which explain the innovator behavior of organizations during the period of crisis refers to the fact that as organizations that innovate once have more or less probabilities to innovate again in subsequent periods (Clausen et al., 2012).

Persistence of innovation usually represented by a model in which the probability for a firm to innovate is explained by means of variables which measure if the enterprise has innovated as well as by means of control variables. The innovation persistence degree of firms therefore depends on various factors. Specific enterprise features which influence persistence are its strategies, managers' attitudes, stage of development, domain of technologies, cash-flows and profits positive trend, among others. Industry demand features the enterprise is part of also influence, such as the profit opportunities and technology.

However, Filippetti \& Archibugi (2011) argue that the national institutional setting has a preponderant role in enterprises behavior and performance.

Clausen et al. (2012) suggest that innovation persistence on the enterprise level may be explained by means of three factors: (1)

Revista de Negócios, v. 20, n. 4, p. 1-10, October, 2016. 
success generates success; that is, an innovation succeeding generates profit needed to invest in new activities or products; (2) dynamic economies of scale and "learning-bydoing", that is, knowledge is cumulative, and current knowledge is the input for new knowledge; (3) enterprises keep innovation activities bound to investment "sunk costs" in I\&D, that is, a firm will hardly discontinue such activities for a year to retake them the following year since the activity is has its basis on the investigators' knowledge.

In such a context one can say enterprises with established innovation activities which invest in $\& \mathrm{D}$, usually big ones, tend to continue innovating along crises periods for the sake of what is called 'innovation persistence'. On the other hand, the agility and flexibility of small and new enterprises allows taking advantage of changes in the environment and new market opportunities. Such scenery suggests the existence of opportunities and menaces from the moments of crisis for the innovation process of firms, what depends in a great extent of the environment in each country.

\section{Barriers and drivers for innovation}

The organization innovation capacity derives from external and internal factors (Berghman et al., 2012; Dervitsiotis, 2010; Fawcett et al., 2012; Hadjimanolis, 1999; MadridGuijarro et al., 2009; Roy et al., 2004). According to Fawcett, Jones e Fawcett (2012), innovation became a team sport. Great innovators depend on external actors to assure great part of the advantage in what refers innovation (Fawcett et al., 2012). Ozman (2009) and Radas e Bozic (2009) state that innovation is more effective when seen as a collective process and that collaboration with other enterprises is an important part of enterprise efforts toward innovation.

The external factors are treated by the authors as: (i) facilitators (Choi \& Krause, 2006; Ettlie \& Reza, 1992; Koberg, Uhlenbruck, \& Sarason, 1996; Rivas \& Gobeli, 2005), (ii) barriers (D'Este, Iammarino, Savona, \& von Tunzelmann, 2012; Fri, 2003; Galia \& Legros, 2004; Holzl \& Janger, 2014; Mohnen \& Roller, 2005) or (iii) both (Calabrese, 2002; Ettlie \& Reza, 1992; Madrid-Guijarro et al., 2009; Radas \& Bozic, 2009).
The impact of such factors can be observed in one or more points of the innovation process (Radas \& Bozic, 2009), depending on its features. Financing difficulties, for instance, may have greater impact in the innovation implementation than in other stages. To Holzl \& Janger $(2013,2014)$, analyzing barriers, more than being a facilitator, allows a view of the enterprises with focus on the innovation process and the definition of policies. It allows the identification of constraints in the process and therefore the decision making toward improvement.

Hadjimanolis (1999) divides external factors related to the supply (supply chain) with the search for environmental factors. Barriers related with supply chains include the difficulty to get information about technology, obtain raw matter and financing barriers. Barriers related to searching refer to the difficulty to get information about consumers' needs, their perception of innovation risks and domestic Nat international market limitations. Environmental factors, in turn, include governmental regulations, measures and antitrust as well as political actions (Hadjimanolis, 1999).

Radas and Bozic (2009) group external factors into: collaboration with other enterprises, connection with knowledge centers and utilization of funds and regulatory support. The authors also point out that collaboration with suppliers may strongly contribute to the organization innovation power. Conceição et al. (2006) point out the relevance of market factors as the sector technological intensity and environmental factors as governmental regulations.

Holzl \& Janger (2014) analyze two types of barriers: (i) financial and (ii) related to knowledge. Financial barriers refer to innovation financial difficulties due to uncertainties concerning refunding/profit. Barriers related to knowledge refer to the acquisition and processing of information needed for innovative activities. Financing difficulties are also approached by Mohnen et al. (2008).

According to Madrid-Guijarro et al. (2009) information about the external environment of organizations, such as market opportunities, technological changes and governmental policies have a great impact upon managers' decision to adopt innovation as a strategy for increase competivity. 
The authors also point out innovation high cost and market uncertainties as important barriers. To Galia and Legros (2004), besides widely discussed factors such as technological opportunities and market level of competition factors such as lack of: (i) qualified staff in the market, (ii) information as meaningful barriers against innovation.

Gnyawali (2013) stresses the importance of participation in strategic alliances or clusters as an innovation facilitator aspect due to the impact upon social interaction intensity, competition strength and the possibility of co-development of projects. Organizational interaction with suppliers is approached by Ettlie and Reza (1992) as a great powerful value addition factor for innovation which according to the authors must be used by enterprises in their innovation strategies.

$$
\text { Golgeci and Ponomarov }
$$
specifically approach the importance of relationship with other actors of the supply chains for the increase of organizations innovation capacity. As firms become more specialized their engagement with supply chain partners increases even more in the innovation process. It becomes fundamental that enterprises align their investigation and internal development strategies with available knowledge in the supply chain, for having a better performance in what concerns innovation (Narasimhan and Narayanan, 2013).

The main reason to collaborate with other organizations is the access to internal unavailable resources; mainly to knowledge (Rese, Gemunden, \& Baier, 2013). In that sense Radas \& Bozic (2009) and Xie et al. (2010) point out the importance of alliances with investigation centers and universities as facilitating factors for the innovation process.

Then we can conclude that there are three main approaches to external aspects having impact upon the innovation process in organizations: (1) Relational factors - facilitators or barriers for the innovation process deriving from the organization relationship with external agents such as clients, suppliers and other partners - centers of investigation, universities, partnerships with other enterprises for the sake of innovation; (2) Environmental factors - themes such as economic uncertainty, governmental policies and legislation; (3) Market factors themes related to the operating sector, market technology intensity and competition.

\section{Hypotheses and development}

Having as objective analyze the several effects of the crisis upon the innovation process and having as basis the barriers and facilitators which have impact upon it, in this section of the study the research hypothesis are defined starting from crossing factors which act as facilitators and as barriers to innovation as well as from the factors which have impact in innovation in times of crisis. Briefly described, the ability of organizations to innovate in times of crisis is linked to factors which increase innovation persistence and to market environmental factors which can potentially generate new opportunities. On the other hand, the main factor making innovation difficult in times of crisis according to literature is financing difficulty. In what concerns barriers and facilitators for innovation, relational, environmental and market factors are identified. Table 1 relates the main factors identified.

Table 1. Relationship between topics

\begin{tabular}{l|l}
$\begin{array}{c}\text { Factors influencing the } \\
\text { innovativeness of organizations } \\
\text { in times of crisis }\end{array}$ & \multicolumn{1}{|c}{$\begin{array}{c}\text { Barriers and drives for } \\
\text { innovation }\end{array}$} \\
\hline Financing difficulty & $\begin{array}{l}\text { Environmental aspects } \\
\text { Market uncertainty }\end{array}$ \\
$\begin{array}{l}\text { Technonoly and raw material } \\
\text { access }\end{array}$ & $\begin{array}{l}\text { Relational aspects and } \\
\text { Positive trend of cash-flows } \\
\text { and profits }\end{array}$ \\
$\begin{array}{l}\text { Industry } \\
\text { characteristics/features } \\
\text { National institutional setting }\end{array}$ & $\begin{array}{l}\text { Environmental and } \\
\text { market related aspects } \\
\text { Market related aspects }\end{array}$ \\
Establishing partnerships & Environmental aspects \\
& Relational aspects
\end{tabular}

Source: Developed by authors

The impact of crisis upon the innovation process of organizations was empirically proved by means of several studies carried out in the last years. Although its importance is recognized and its impact on innovation persistence is acknowledged as high (Clausen et al., 2012), the investment in $\mathrm{R} \& \mathrm{D}$ is not the only innovation source of innovation - other inputs include external knowledge (e.g. in the form of cooperation, alliances, or licensing), and internal activities like design, marketing, training, etc. Thus, to check different influences on the crisis

Revista de Negócios, v. 20, n. 4, p. 1-10, October, 2016. 
effect upon the process and the results of organization innovation, the first hypothesis presented is:

H1: The crisis has impact upon the innovation process in different ways - not restricted to investment reduction.

The success of innovation process depends on the enterprise ability to overcome obstacles ahead (D'Este et al., 2012), as well as to empower the existing facilitators. Taking into account the existence of relational, environmental and marketrelated external factors which have impact upon innovation in organizations, the second hypothesis presented is:

H2: The crisis affects the relational, environmental and market related aspects which have an impact upon innovation and change the drivers and barriers.

The recession periods bring together a game of difficulties for enterprises, including the innovation process. "However, economic crises also provide an opportunity for firms and entire nations to restructure productive facilities and to explore new opportunities. Smart companies do perceive that an economic crisis will not last forever and that a recovery will sooner or later arrive" (Archibugi et al., 2013b, p. 1247). Thus, the third hypothesis to be tested is:

H3: Drivers and barriers for innovation influenced by crises create new opportunities and threats to innovation within organizations.

Last, considering that the crisis impacts countries with different intensities, we have started from the principle that the more severe the crisis, the greater will be the impact in innovating activities. Thus, the last hypothesis of the study is:

H4: Companies located in countries most affected by crisis faced greatest difficulties concerning innovating in such periods.
To test the Hypothesis, after the literature review, we used two types of information. Secondary data, especially from The Global Innovation Index, to compare the context of innovation in Portugal and Brazil in three different periods - before the crisis, during the crisis and after the crisis (or during the recovery of the economies); and primary data from the case studies, using data from the same three periods. The case studies were developed in Portuguese and Brazilian enterprises and were used for the analysis of the practical effects of the identified aspects in two distinct realities in what concerns the economic crisis.

The analysis on the reality of the countries starts on the principle that the influence of the crisis upon society and the enterprises varies according to the reality in each country. The economic integration and globalization processes have great impact upon the States which start being influenced by external factors and, as a consequence have its sovereign compressed (Fernandes, 2012). In times of global severe recession like that beginning in 2008 , the fragility of countries economies makes that influence intensified so that its effects reach different aspects of organization and people's lives. The selected countries for this investigation - Portugal and Brazil - were impacted in distinct ways by the crisis and its effects upon innovation will be further analyzed. For the empirical analysis on the crisis effects upon innovation, an option was made to carry out the study of multiple cases. A case study is an empirical research that investigates a contemporary phenomenon within a real life context, especially when barriers between the phenomenon and the context are not clearly evident (Yin, 2009). The use of multiple case studies confers more replication potential and reduces results vulnerability. Four enterprises were selected - two in Portugal and two in Brazil - whose features are presented in Table 2. Interviews were made with key representatives of the enterprises.

\section{Data and Methodology}

Table 2. Main features of enterprises investigated

\begin{tabular}{c|cccc} 
Company & Company & Company & Company \\
$\mathrm{A}$ & $\mathrm{B}$ & $\mathrm{C}$ & $\mathrm{D}$ \\
\hline
\end{tabular}

Revista de Negócios, v. 20, n. 4, p. 1-10, October, 2016. 


\begin{tabular}{|c|c|c|c|c|}
\hline Country & Portugal & Portugal & Brazil & Brazil \\
\hline Sector & $\begin{array}{l}\text { Mold } \\
\text { industry }\end{array}$ & $\begin{array}{c}\text { IT- } \\
\text { passenger } \\
\text { transport } \\
\text { sector }\end{array}$ & $\begin{array}{l}\text { Passenger } \\
\text { transport } \\
\text { sector }\end{array}$ & $\begin{array}{l}\text { Textile } \\
\text { industry }\end{array}$ \\
\hline Foundation & 1947 & 1992 & 1955 & 1994 \\
\hline $\begin{array}{l}\text { Number of } \\
\text { employees }\end{array}$ & 26 & 11 & 705 & 80 \\
\hline $\begin{array}{l}\text { Annual } \\
\text { revenues }\end{array}$ & $\begin{array}{c}1.200 .000 \\
€\end{array}$ & $\begin{array}{c}700.000 \\
€\end{array}$ & $\begin{array}{c}17.000 .000 \\
€\end{array}$ & $\begin{array}{c}4.000 .000 \\
€\end{array}$ \\
\hline $\begin{array}{l}\text { Position of } \\
\text { interviewee }\end{array}$ & CEO & Director & CEO & Supervisor \\
\hline $\begin{array}{l}\text { Target } \\
\text { market }\end{array}$ & $\begin{array}{l}\text { National } \\
\text { and intern. }\end{array}$ & National & Regional & National \\
\hline $\begin{array}{l}\text { Types of } \\
\text { innovation }\end{array}$ & $\begin{array}{l}\text { Product } \\
\text { and } \\
\text { process }\end{array}$ & $\begin{array}{l}\text { Product } \\
\text { and } \\
\text { process }\end{array}$ & Process & Process \\
\hline
\end{tabular}

Source: Developed by authors

\section{Results and discussion}

In this section we discuss our results in connection with the hypotheses. Firstly, an analysis of the crisis effect taking place in the two countries, using secondary data, is held in order to contextualize innovation. Thereafter, we analyze the results of the case studies.

\subsection{Innovation and crisis in Portugal}

Europe has undergone the period of crisis started in 2008 intensively. Portugal, in its turn, was one of the countries which faced more difficulties in that period with the reduction of the Gross Domestic Product (GDP) in four of the five last years (PORDATA, 2014). To Fernandes (2012), great part of the problems the Portuguese economy today faces is directly or indirectly linked to decisions taken in the late 90's related to joining the Euro. At the time, much was discussed about the demands and risks of adopting a single strong currency by fragile economies like the Portuguese. However; the desire for development left such worries behind.

In what refers innovation during the crisis period Portugal has shown to be able to overcome difficulties maintain or even improve results achieved in the previous years. Data from The Global Innovation Index, annual report elaborated by INSEAD, Cornell University and

World Intellectual Property Organization - WIPO, which demonstrates the reality concerning innovation in more than 143 countries, reveal that Portugal raised from the 39 th position in the ranking in 2007 to the 32nd in 2014 (Cornell University et al., 2014).

Another annual report - the Eurobarometter - elaborated by the European Commission with data from the 28 member states of the European Union reveals the highlight of Portugal in the European scenery in a great number of indicators. Looking at the results it can be observed, for example, that Croatia (53\%) and Portugal $(52 \%)$ are the only countries where at least half of all companies say they have introduced new or significantly improved services since January 2011. Companies in Italy (49\%), Portugal and Malta (both 48\%) are the most likely to say they have introduced new or significantly improved goods and companies in Portugal (45\%), Malta and Italy (both $44 \%$ ) are also the most likely to have introduced new or significantly improved marketing strategies since January 2011. Companies in Portugal (47\%) and Cyprus $(43 \%)$ are the most likely to have introduced new or significantly improved organizational structures. Finally, companies in Portugal (44\%), Malta (43\%) and Croatia (41\%) are the most likely to have innovated in the area of processes. A broad overview of these results across Member States shows companies in Portugal are consistently amongst the top three most likely to have introduced any of these innovations since January 2011 (European Commission, 2014). In addition, only in Portugal more than half of companies say they have innovations and commercialize them.

\subsection{Innovation and crisis in Brazil}

Unlike Portugal, Brazil is not taken as one of the countries which were most affected by the economic crisis beginning in 2008. However, Brazilian economy, unlike that of other countries constituting the BRICS, does not reveal representative numbers in the last years. Brazilian GDP raised 7, 5\% in 2010, however has presented more modest results thereafter; with a growth of 2 , $7 \%$ in $2011,1,00 \%$ in 2012 and 2, 5\% in 2013(Central Bank of Brazil, 2014). The expected results for 2014 are under 1, 00\%.

Concerning innovation, also according to data from The Global Innovation Index, Brazil occupies the 61st position in the rank of the 143 countries analyzed. In 2007 the country occupied the 40th position and in 2011 the 47th, what

Revista de Negócios, v. 20, n. 4, p. 1-10, October, 2016. 
reveals that during the period of crisis Brazil showed a considerable decrease in its innovation performance Considering, as already mentioned, that Brazil was not one of countries most affected by the crisis, it can be Said that the policies adopted by the government and the enterprises efforts have not had the effect expected.

However, it could be observed that Brazil has reached its worst results in 2013, with a slight improvement in 2014. Brazil is ranked 61st (up from 64th in 2013), 16th among upper middleincome countries (up from 21st), and 5th in the region (up from 8th). Brazil is one of the four countries in the region that improves in the rankings this year (Cornell University et al., 2014). Brazil ranks as 63rd in the Input SubIndex, 64th in the Output Sub-Index and as 71st in efficiency. For the report authors the country shows relative strengths in Business sophistication (37th), Infrastructure (60th), Human capital and research (62nd), Creative outputs (64th), and Knowledge and technology outputs (65th). Brazil's strongest performance is in the Knowledge absorption sub-pillar, ranking in the top 30 for three out of the four variables. Brazil's weaknesses remain in Institutions (95th), particularly in the Business environment sub-pillar (137th) (Cornell University et al., 2014).

Based in such analysis, one can say that although Portugal has undoubtedly suffered the effects of the crisis to a greater extent as compared to Brazil, what can be proved by means of the evolution of the GPD of both countries in the last years, data referring innovation reveals divergent scenery. The analyzed reports demonstrate Portugal improved its performance concerning innovation during the period of crisis; on the other hand, Brazil presented a decrease in results in the same period.

\section{Conclusions}

The literature on the effects of crisis upon the innovation process explores financial and economic aspects thoroughly, and other aspects are rarely addressed. However, the impact of crisis upon innovation is not constrained to financing capability, but it also comprises other aspects such as market uncertainty increase and customers' lack of response in what concerns innovation, what is in accordance with our first hypothesis.
With basis on the case studies investigated and the analysis of secondary data from Portugal and Brazil, it is concluded that the crisis affects/impacts companies and countries differently. With regard to the second hypotheses, the crisis effects are more clearly observed in environmental and market related factors as compared to relational factors. Enterprises located in Brazil, however, revealed major difficulty for establishing partnerships along and after the period of crisis.

Literature review, as well as the case studies analyzed also suggests the emergence of opportunities and threats to innovation processes in periods of crisis. Although Portugal has acknowledged having suffered the crisis effect to a greater extend if compared to Brazil, data concerning innovation reveal different scenery. Portugal improved its performance concerning innovation during the crisis. Brazil, on the other hand, decreased in results achieved in the same period. We can also conclude that, given the scarcity of resources in times of crisis and in the quest for competitiveness, many companies transfer their efforts from product innovation to process innovation, cheaper and with the potential to reduce costs.

Finally, we can say that the crisis has an impact upon innovation barriers and facilitators intensity in different ways generating new opportunities and threats and also that enterprises which adapt themselves more easily to constraints imposed by the economic crisis tend to present better results related to innovation.

This study may contribute for enterpriserelated as well as academic purposes since it classifies factors which influence innovation positive or negatively in times of crisis. Its main limitation is the number of countries involved (only two) as well the number of case studies (only four). The enterprises studied also diverge as to size and sector, what also increases difficulty to compare and generalize findings. Finally, Brazilian companies revealed instability in what refers innovation strategies, making the analysis of crisis effects more difficult and less accurate. The main recommendation for further investigation is to test the hypotheses by making surveys comprising more firms and countries and with focus on specific firm sizes and sectors.

\section{References}

Revista de Negócios, v. 20, n. 4, p. 1-10, October, 2016. 
Archibugi, D., Filippetti, A., \& Frenz, M. (2013a). Economic crisis and innovation: Is destruction prevailing over accumulation? Research Policy, 42(2), 303-314.

Archibugi, D., Filippetti, A., \& Frenz, M. (2013b). The impact of the economic crisis on innovation: Evidence from Europe. Technological Forecasting and Social Change, 80(7), 1247-1260.

Berghman, L., Matthyssens, P., \& Vandenbempt, K. (2012). Value innovation, deliberate learning mechanisms and information from supply chain partners. Industrial Marketing Management, 41(1), 27-39.

Calabrese, G. (2002). Small-medium car suppliers and behavioural models in innovation. Technology Analysis \& Strategic Management, 14(2), 217-225.

Central_Bank_of_Brazil. (2014). Banco Central do Brasil. 2014. http://www.bcb.gov.br/ptbr/paginas/default.aspx. (accessed November 10, 2015).

Choi, T. Y., \& Krause, D. R. (2006). The supply base and its complexity: Implications for transaction costs, risks, responsiveness, and innovation. Journal of Operations Management, 24(5), 637- 652.

Clausen, T., Pohjola, M., Sapprasert, K., \& Verspagen, B. (2012). Innovation strategies as a source of persistent innovation. Industrial and Corporate Change, 21(3), 553-585.

Cornell_University, INSEAD, \& WIPO, W. I. P. O. (2014). The Global Innovation Index 2014: The Human Factor in Innovation Fontainebleau, Ithaca, and Geneva.

D'Este, P., Iammarino, S., Savona, M., \& von Tunzelmann, N. (2012). What hampers innovation? Revealed barriers versus deterring barriers. Research Policy, 41(2), 482-488.

Dervitsiotis, K. N. (2010). A framework for the assessment of an organisation's innovation excellence. Total Quality Management \& Business Excellence, 21(9), 903-918.

Ettlie, J. E., \& Reza, E. M. (1992). Organizational Integration and Process Innovation Academy of Management Journal, 35(4), 795-827.

European_Commission. (2014). Flash Eurobarometter 394: The role of public support in the comercialisation of innovation. Brussels: European Commission, Directorate-General for Enterprise and Industry.
Fawcett, S. E., Jones, S. L., \& Fawcett, A. M. (2012). Supply chain trust: The catalyst for collaborative innovation. Business Horizons, 55(2), 163-178.

Fernandes, J. P. T. (2012). A Europa em Crise. Vila do Conde: QuidNovi.

Filippetti, A., \& Archibugi, D. (2011). Innovation in times of crisis: National Systems of Innovation, structure, and demand. Research Policy, 40(2), 179-192.

Fri, R. W. (2003). The role of knowledge: Technological innovation in the energy system. Energy Journal, 24(4), 51-74.

Galia, F., \& Legros, D. (2004). Complementarities between obstacles to innovation: evidence from France. Research Policy, 33(8), 1185-1199.

Gnyawali, D. R., \& Srivastava, M. K. (2013). Complementary effects of clusters and networks on firm innovation: A conceptual model. Journal of Engineering and Technology Management, 30(1), 1-20.

Hadjimanolis, A. (1999). Barriers to innovation for SMEs in a small less developed country (Cyprus). Technovation, 19(9), 561-570.

Holzl, W., \& Janger, J. (2014). Distance to the frontier and the perception of innovation barriers across European countries. Research Policy, 43(4), 707-725.

Kanerva, M., \& Hollanders, H. (2009). The Impact of the Economic Crisis on Innovation Analysis based on the Innobarometer 2009 survey INNO Metrics Thematic Paper (pp. 30). Brussels: European Commission.

Koberg, C. S., Uhlenbruck, N., \& Sarason, Y. (1996). Facilitators of organizational innovation: The role of life-cycle stage. Journal of Business Venturing, 11(2), 133-149.

Madrid-Guijarro, A., Garcia, D., \& Van Auken, H. (2009). Barriers to Innovation among Spanish Manufacturing SMEs. Journal of Small Business Management, 47(4), 465-488.

Mohnen, P., \& Roller, L. H. (2005). Complementarities in innovation policy. European Economic Review, 49(6), 1431-1450.

PORDATA. (2014). PORDATA. http://www.pordata.pt/Home (accessed November 10, 2015).

Radas, S., \& Bozic, L. (2009). The antecedents of SME innovativeness in an emerging transition economy. Technovation, 29(6-7), 438-450.

Ranga, M., \& Etzkowitz, H. (2012). Great Expectations: An Innovation Solution to the

Revista de Negócios, v. 20, n. 4, p. 1-10, October, 2016. 
Contemporary Economic Crisis

INTRODUCTION. European Planning Studies, 20(9), 1429-1438.

Rivas, R., \& Gobeli, D. H. (2005). Accelerating innovation at Hewlett-Packard. ResearchTechnology Management, 48(1), 32-39.

Roy, S., Sivakumar, K., \& Wilkinson, I. F. (2004). Innovation generation in supply chain relationships: A conceptual model and research propositions. Journal of the Academy of Marketing Science, 32(1), 61-79.

Schumpeter, J. A. (1943). Capitalism, Socialism, and Democracy. London and New York: Routledge.

Yin, R. K. (2009). Case study research: design and methods (4 ed.). London: Sage Publications. 